\title{
Lexis
}

Journal in English Lexicology

$6 \mid 2011$

Diminutives and Augmentatives in the Languages of the World

\section{Suffixal Diminutives and Augmentatives in Slovak}

A Systemic View with Some Cross-Linguistic Considerations

\section{Ada Böhmerová}

\section{OpenEdition}

\section{Journals}

Electronic version

URL: http://journals.openedition.org/lexis/429

DOI: $10.4000 /$ lexis.429

ISSN: 1951-6215

Publisher

Université Jean Moulin - Lyon 3

\section{Electronic reference}

Ada Böhmerová, « Suffixal Diminutives and Augmentatives in Slovak », Lexis [Online], 6 | 2011, Online since 27 March 2011, connection on 24 September 2019. URL : http://journals.openedition.org/lexis/ 429 ; DOI : 10.4000/lexis.429

This text was automatically generated on 24 September 2019.

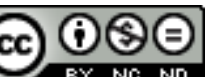

Lexis is licensed under a Creative Commons Attribution-NonCommercial-NoDerivatives 4.0 International License. 


\title{
Suffixal Diminutives and Augmentatives in Slovak
}

\author{
A Systemic View with Some Cross-Linguistic Considerations
}

Ada Böhmerová

\section{Introduction}

1 This paper is intended as a contribution to the recently foregrounding interest in the research of the presence of evaluative morphology in languages of the world. It identifies and analyzes the suffixal diminutive and augmentative morphs present in Slovak, a Central-European West-Slavic language, their distribution, systemic place and communicative functions, devoting attention to phenomena and features that are linguistically rather wide-spread or are more language-specific in this onomasiological category.

2 It arose as part of a more extensive study focusing on contrastive research of the status of suffixal diminutives and augmentatives and their communicative functions in Slovak and in English, in search of the possible synchronical as well as diachronical typological and genetic reasons for the existing systemic differences.

3 The present paper deals with morphological derivative means of quantitative evaluation from the formal and functional points of view. While the descriptive approach to linguistic phenomena constitutes a principal part of any analysis, their systemic communicative role can only be revealed through functional linguistic analysis advocated for e.g. already by Mathesius [1929] and the later members of the Prague School of Linguistics, above all Vachek [1964]. The need for such approach is stressed also in more recent linguistics [cf. Horecký 1978], and in connection with the research of English diminutives e.g. by Schneider [2003].

4 Though suffixal diminutives and augmentatives are a common and frequent phenomenon in the Slovak language, during the research it became evident that the extent of descriptive and theoretical materials concerning the theme is rather modest, limited to very brief mentions in textbooks, with the exception of some in-depth 
analyses of several specific sub-themes, but with no detailed treatment of these morphological evaluative means.

Hence, before proceeding to any synthetic statements it was necessary to carry out the basic morphological analysis of the system of suffixal diminutives and augmentatives in Slovak the results of which form part of the paper.

With regard to the approach that we have selected, this paper is not data-based per se, in the sense that it does not investigate a particular set of excerpted or textually or otherwise collected or generated data, but it comprizes a variety of data excerpted from linguistic monographs, textbooks, articles, dictionaries (including corpus-based ones), as well as and empirical native-speaker experience.

7 Internationally, the recent interest in evaluative morphology is manifested in a number of publications, whether oriented upon one language or cross-linguistically, much of the impetus having been given by Scalise [1984]. A challenging multilingual and universal view of evaluative morphology is presented by Stump [1993] and Bauer [1997], and from among numerous other sources, diminutives in Italian, German and some other languages are compared by Dressler and Merlini Barbaressi [1994], while Schneider [2003] devotes his monograph to a very thorough research and presentation of diminutives in English. Within the specific themes of evaluative morphology much investigation has been done in search of phonetic symbolism in e.g. by Bauer [1996], and more recently by Štekauer et al. [2009], Gregová and Panocová [2009], and Körtvélyessy [2010].

8 As to comparisons with Slovak, papers on evaluative morphology include e.g. Gladkova [2010] dealing with diminutives and augmentatives in Bulgarian and Slovak, Nábělková [2010] and Gladkova [2010] comparing Czech and Slovak as very closely related Slavic languages. From the point of view of their occurrence in translations of literary texts into and from English, English and Czech diminutives were scrutinized by Chamonikolasová \& Rambousek [2007], and Káňa [2010] recently analyzed Czech substantival diminutives and their counterparts in German and in English.

With regard to Slovak itself, no detailed systemic research of the situation concerning morphological evaluative diminutives and augmentatives has been found, and the situation is similar also in the sphere of comparing these linguistic phenomena in Slovak with the ones in English or within multilingual considerations. However, crosslinguistic comparisons are a desideratum as they can not only result in identifying the parallelisms and differences between the languages studied, but from the perspective of a foreign language can help to reveal some phenomena and systemic relationships otherwise not fully evident in the particular language, as well as assist in seeing the linguistic situation in wider linguistic contexts.

10 In this paper Section 1 presents the theoretical background of the theme, Section 2 formulates the aims and method followed in the research, Section 3 deals with the general characteristics of means of quantitative evaluation in Slovak, Section 4 is devoted to suffixal diminutives in various word-classes, section 5 to augmentatives, Sections 6 and 7 present some final observations concerning the pragmatically potential opposite polarity of these evaluative lexical means and the question of their iconicity, followed by conclusions and suggestions for future research. 


\section{Theoretical Background}

11 The semantic category of dimension or size is hypothesized as being a universal. It is a modificational category and can be expressed:

12 1. lexically, primarily by adjectives, as indicated in Universal \# 1196 (originally No \# 1200 stated by Dixon, 1977):

IF any other semantic types are expressed by words of the word class of adjectives, THEN members of the semantic types AGE, DIMENSION, VALUE and COLOR are likely also to be expressed by adjectives.

13 2. morphologically, within the semantically wider category of evaluative derivative morphology, without necessarily any restriction/limitation to the particular wordcategories.

14 While expressing dimension, size, extent, etc. lexically can reasonably be expected to occur universally, their morphological expression, though relatively widespread, seems to be more restricted, language or language-family/families or language-type specific, with a number of differences in the range of evaluative morphs, their valency, productivity, frequency of occurrence, as well as in their semantic content and communicative-pragmatic functions.

With regard to the place of morphological derivation within linguistic disciplines, we do not consider it part of grammar but part of onomatology within lexicology. While the function of morphs in grammar is primarily to express syntactical relationships within the paradigms of the existing grammatical system, the function of morphs in word-formation is primarily to change their semantic content and within the onomasiological process their onomatological structure, hence lexicology is a linguistic discipline in its own right. This is in line with Horecký's defining lexicology as a science dealing with the lexis [1979: 86] and with Furdík's statement that "lexicology as a linguistic discipline investigates the lexical level of the language, including its marginal areas" [Furdík; in Ondrus, Horecký, Furdík 1980: 8]. According to Filipec and Čermák lexicology is "the theory of the lexis, carrying out its basic research, i.e. describing and explaining the lexical units of various types, words, collocations and phrasemes, their relationships and partial systems" [1985: 13].

The basic function of the derivative formation of diminutives and augmentatives entails the semes of (relatively) small or large size respectively. It is included in the modificational type of onomasiological category, together with the change of gender (i.e. feminization), the formation of the names of the young of animals, and of substantives expressing collectiveness, as stated already by Dokulil [1962; in Štekauer 2006: 34]. For Slovak, Furdík [2004: 92] also includes the formation of relational lexical units (e.g. izba 'room' $\rightarrow$ predizba 'anteroom'), and negativization forming contradictory antonyms (e.g. plavec 'swimmer' $\rightarrow$ neplavec 'non-swimmer'). Similarly to Furdík with regard to Slovak, e.g. also Schneider for English considers for means of evaluative the prefixed morphs as mini-, mikro-(Sk)/micro- and maxi- and makro-(Sk)/macro- [2003: 17], etc.; for super- considered as augmentative prefix cf. also e.g. Aronoff [1976: 69, as stated by Plag 2009: 103]. Though such prefixal morphs, which from the semantic point of view could also be classified as minimizers and intensifiers (these characteristics to some extent being also shared by diminutive and augmentative suffixes), are undoubtedly semantically and pragmatically relevant for quantitative evaluative modification, they are not included in the scope of the present paper. Neither analyzed 
at this stage, though linguistically and cross-linguistically very interesting, and occasionally referred to in our text, are the so-called 'frozen diminutives', i.e. lexical units in which the quantitative feature became fully or partly neutralized within their lexicalization.

We primarily focus on quantitative diminutivisation and augmentation. Nevertheless, we also devote attention to the fact that diminutive and augmentative derivatives tend to evaluative expressive polarization due to their potential polysemy and the systemic and situational, i.e. pragmatic possibility of their partial quantitative desemantization, the diminutives prevailingly, though not exclusively, expressing positive attitudes and the augmentatives negative ones. "Because of the possibility of interpreting diminution and augmentation in affective rather than purely objective terms (Wierbiczka [1980: 53ff.]; Szymanek [1988: 1006ff.] in Stump [1993: 1]), morphological expressions of diminution or augmentation are not always discrete from those of endearment or contempt..." As stated e.g. by Furdík [2004: 111], in Slovak some modificational categories serve directly for forming expressive lexical units.

Where evaluative derivative morphology is present in the system of the language, it can lexically and syntactically co-occur with the linguistically primary lexical expression of dimension or size for emphasis, or for dimension-related communicative harmony, both of which can be related to communicative situation, genre, style or register and parts of the paper are devoted to the complexity of their functioning in Slovak.

\section{Aims and Method}

Slovak as an Indo-European language shares many linguistic, and in their number also morphological features with other related languages, and to some extent probably alsowith unrelated languages within universal linguistic contexts.

Slovak as a Slavic language has an "affluence of evaluative morphology" [Štekauer et al., 2009: 126], mostly diminutive, with a relatively wide range of their distribution and semantic functions, and has several augmentative suffixes as well, though of more limited distribution and functionality.

21 The aims of the paper are the following:

1. to present our own research into the suffixal means of Slovak morphological diminutive and augmentative morphology, their typology, word-class distribution and systemic status in word-formation, with some cross-linguistic observations;

2. to give the basic semantic features and pragmatic functions of suffixal diminutives and augmentatives, including notes on their dynamism;

3. to identify the potential areas for future research.

In our research we use the method of synchronic description of the particular morphological and lexical means as combined with the method of the functional analysis of their semantic and pragmatic features within the system of the Slovak language. 


\section{Suffixal Means of Quantitative Evaluation in Slovak} infrequent.

Slovak can morphologically, i.e. by suffixation, express both diminutiveness and augmentativeness, and does so by native, etymologically slavic morphological means.

Encyklopédia jazykovedy [Mistrík 1993: 493] with regard to Slovak defines diminutives as the words (mostly substantives, less frequently adjectives, adverbs and verbs) which express smaller dimension, lower degree of something, or a certain attitude to the verbal action, giving examples of several nominal and adjectival diminutives and one example of an adverb and a verb. It is stated that diminutives tend to become expressive and, prevailingly, the attitude expressed by them is positive, though can also be used negatively, and their semantic content can be hypocoristic or nondiminutive. In the same source augmentatives are defined as words denoting a relatively larger dimension or larger extent of some feature or quality than is adequate or expected, and their expressivity is mostly negative, only rarely positive [1993: 73].

In Slovak as a language of a inflectional grammatical type and a inflectional lexical type, in word-formation is combined with the agglutinative type [cf. Furdík 2004: 112], inflectional formation of diminutives is systemically and their textual occurrence is frequent and widespread. The first linguist who dealt with Slovak diminutives, though only cursorily, was Czambel [1919]. Suffixal diminutives are formed by a number of morphological means in the category of nouns, adjectives and adverbs, with a high productivity of diminutivisation or even graded diminutivisation, often accompanied by a wide range of expressive possibilities. Slovak also forms augmentatives by suffixal derivation, though in comparison to the system of diminutives they have a relatively marginal status. They occur with substantives, adjectives and adverbs. Synchronically only several augmentative suffixes are used, and textually augmentatives are rather

Similarly to the situation existing in many other languages, in Slovak grammatical inflection and word-formative derivation have for long been theoretically considered as relatively distinct linguistic processes. Hence, in the standard Slovak linguistic sources suffixal diminutives and augmentatives are included not in morphology [e.g. not in Oravec et al., 1988], but in lexicology [Horecký, 1971; Ondrus et. al., 1979], or specifically in monographs on word-formation [Furdík, 2004] where the basic information on the forms and usage of these evaluative derivatives is presented, though only very briefly. In what follows we will try to provide a considerably more detailed representation and analysis of the morphological situation in the area of Slovak diminutives and augmentatives.

The largest number of derivative suffixal diminutives are formed in the word category of substantives by means of one of a number of diminutive morphs. However, similarly to some other languages from the Slavic family, not only substantives but several other word-categories can be morphologically diminutivised. In addition to those given in the available theoretical sources, i.e. substantives, adjectives, adverbs and verbs, our data show that to a very limited extent (and only when substantivized), diminutives can also be formed from numerals, and exceptionally (as ad-hoc formations) from interjections and even a pronoun.

In a corpus-based contrastive research of the Czech and Slovak category of diminutiveness Gladkova (forthcoming) distinguishes the centre, i.e. diminutive 
substantives, and the periphery, i.e. diminutives from other word categories, which could be accepted also for our data, although at least some diminutivised adjectives and adverbs, due to their high frequency, could also qualify for the centre.

With regard to the range of the word categories which can be diminutivised, the linguistic situation in Slovak basically complies with Universal \# 2006 [originally \# 2015; Bauer 1997], as well as with its originally suggested hierarchy. However, in Slovak diminutivisation of adverbs is more primary and much more productive than that of verbs, the diminutive derivability of pronouns and interjections is hierarchically also reversed and together with numerals extremely limited, with determiners not present as a word-class in Slovak.

\section{Suffixal Diminutivisation}

\subsection{Suffixal Substantival Diminutives}

Morphological suffixal diminutivisation of substantives is deep-rooted in the Slovak morpho-lexical system, with practically unlimited productivity among concrete substantives [cf. Furdík 2004: 90], and occurrence also among other substantives, hence diminutivisation of substantives is an open word-formative category. It can be expressed by a number of suffixes and is highly systemic. The distribution of nominal diminutivising suffixes is gender-sensitive, hence different sets of $-k$-type diminutive suffixes (with the allomorph $-\check{c}$ - and historically also $-c$ ) are used for the particular genders. At the same time, basically (with only the exception of one polysemantic suffix), diminutive derivation observes what Stump [1992] denotes as categorypreserving rules.

Horecký's list [1971: 163-167] includes the Slovak diminutive suffixes which (with his and some other examples) could be presented in the following Table 1 :

Table 1: Basic diminutive suffixes in Slovak

\begin{tabular}{|l|l|l|l|}
\hline Gender & Suffix & Example & \\
\hline & & Base & Diminutive \\
\hline Masculine & $-\imath k /-i k$ & most 'bridge' & mostík/môstik \\
\hline & & žiak 'pupil' & žiačik \\
\hline & $-o k$ & list 'leaf; letter' & lístok \\
\hline & $-e c$ & zvon 'bell' & zvonec \\
\hline & $-c ̌ e k /-t e k$ & syn 'son' & synček \\
\hline Feminine & $-k a$ & orech 'nut' & orieštek \\
\hline & & loĎ 'ship' & loĎka \\
\hline
\end{tabular}




\begin{tabular}{|l|l|l|l|}
\hline & & ulica 'street' & ulička \\
\hline & -ička/-ôčka & izba 'room' & izbička \\
\hline & fialka 'violet' & fialốcka \\
\hline & -enka/-ienka/-inka & šabL'a 'sword' & šablenka \\
\hline Neuter & -ko sloboda 'freedom' & slobodienka \\
\hline & -ičko/-iečko & duša 'soul' & dušinka \\
\hline & pole 'field' & políčko \\
\hline & -očko/-ečko & miesto 'place' & miestočko/-ečko \\
\hline & & víno 'wine' & vínečko \\
\hline
\end{tabular}

In most substantival diminutives the suffix with the consonant $-k$ - or its palatalized allophone $-\check{c}-$ (the palatalization dated into the 5th or 6th century), or else the combination of both is used, with an accompanying vowel, if final, then in feminine $-a$ and in neuter -0 .

Historically, the suffixs with the element $-k$ - i.e. $-i k /-i k,-o k,-k a,-k o$, etc. go back to the ProtoIE suffix * $q o$, and often combine with the OCS suffix -bcb which became palatalized, i. e. - ̌̌ek, -ička, -očko, etc. This potential co-occurrence of diminutive suffixes can be considered for (co-)forming the historical basis for the gradability of diminutives, e. g. víno 'wine' - vínko - vínečko in Slovak, as well as in other Slavic languages.

34 As evident from the examples, typically for inflectional languages, on the morphological boundary (under certain conditions) there often occurs modification of the final consonant of the base and/or lengthening or diphthongization of the previous vowel.

The productivity and frequency of these diminutive suffixes, as well as their distribution within each gender, vary. Some of them can alternatively be used with the same base, e.g. oriešok and orieštek, others do not allow for any alternation, i.e. žiačik. Included in the list is also the suffix -ec. Horecký [1971: 165] points out that it is relatively rare, its diminutive meaning is present e.g. in names of things like domec (from dom 'house'), zvonec (from zvon 'bell'), etc., and in names of animals, e.g. baranec (from baran 'ram'). However, as he states, in most cases derivatives with this suffix have already lost their diminutive meaning and are either synonymous to their bases, e.g. kahan - kahanec '(open) burner; pit lamp' or denote different phenomena, e.g. klin 'wedge' vs. klinec 'metallic, etc nail'. It can be stated that at present the Slovak suffix -ec is not productive any more, as indicated also by Gladkova [2010] who in her research comparing Czech and Slovak diminutives qualifies it as being historical. From the 
onomasiological point of view Furdík [2004: 43] gives it as an example of a 'redundant formant' which can formally be segmented but is not the bearer of onomasiological base, it "becomes desemantized and the meaning of diminutiveness gets lost." Consequently, he says that the status of this suffix is between a semantically 'full' formant (suffix) and a semantically 'empty', redundant formant. The fact that e.g the word kahanec is in Krátky slovník slovenského jazyka (KSSJ) defined as (malý) kahan '(small) burner or lamp', with malý given in brackets, is interpreted by him as indicating only the potential validity of diminutiveness. We can add that $-e c$ testifies to the dynamic developments in the system of Slovak diminutive suffixes as it has lost both its productivity and (with the exception of very few petrified lexical units) also its diminutive semantic content. In some cases, synchronically the former bases do not exist any more, e.g. there is none for otec 'father'.

However, historically, -ec was a diminutive suffix and as the only one in old Church Slavic (OCS) is given by Večerka [1984: 2009] in the form -ьcb, e.g. oblačbcb 'cloudlet', сvětbcb 'little flower', ptъtěnbcb 'birdie' [cf. Večerka 1984: 209].

The set of Slovak diminutive morphs includes the feminine suffix $-k a$ in connection with which Furdík [2004: 63] speaks about word-formative polysemy, i.e. the phenomenon when in onomasiological categories one formal word-formative structure expresses several differing but mutually related onomasiological structures, in this case the type Base ${ }_{s}+-k a$ of feminized substantives [cf. Böhmerová 2006: 32], e.g. geodet+ka (geodesist+FEM), as well as the type forming e.g. the diminutive map+ka 'mapa+DIM'. We can point out that the polysemy of the structures with the modificational suffix $-k a$ testifies to the semantic closeness of the modificational categories of feminization and diminutiveness, as feminine references can conventionally tend to entail the semantic component "small size".

Such semantic relatedness occurs also in the word-formative systems of other languages, not only in Slavic ones, cf. e.g. English usherette vs. statuette. In contrast to the situation in Slovak, in English the usage of -ette, as well as the feminizing suffix -ess, has been "increasingly considered as sexist" [Schneider 2003: 95]. However, it should be pointed out that of importance in this context is the fact that such socio-linguistic attitude is rather language-specific, conditioned also by the lexical and grammatical system of the particular language. Consequently, such sexist sensitivities and interpretations as exist in English could not arise e.g. in a language as Slovak where for grammatical reasons each substantive must have the grammatical category of gender, with the due morphological markers. Hence, when referring e.g. to a female painter, Slovak cannot use the masculine form maliar but only the derivative maliarka "painter+ $\left.\mathrm{FE}^{\prime}\right)$ (with the exception of generic references). Due to such grammatical and onomatological indispensability of feminative derivatives in Slovak such lexical units cannot become the tool or target of any feminist, antifeminist or 'politically-correct' movements [Böhmerová 2004: 50-51].

of diminutive semantic content is also the suffix $-a$ which can either express small size, or refer above all to the young of an animal, or have positive expressivity. The examples of its derivatives could include $\mathrm{N}$ vtáča (from M vták 'bird'), $\mathrm{N}$ kvieřa (from $\mathrm{M}$ $k v e t$ 'flower'), $\mathrm{N}$ žieña (from $\mathrm{F}$ žena 'woman'). In contrast to the situation occurring in the case of other diminutive suffixes where the diminutive always preserves the wordcategory of the base, the derivatives with - $a$ result in Neuter substantives, regardless of the gender of their base (cf. the genders of the bases of the examples above). We 
suppose that the reason can be seen in the fact that the suffix - $a$ contains not only the seme 'small' but potentially also the semes 'offspring', 'the young of', and substantives with such meaning tend to be Neuter in Slovak. However, as indicated above, this suffix is polysemantic, and e.g. the derivative žieňa (from žena 'woman') potentially entails the modificational semes 'small, frail, pleasant, nice'. The historically related variant of this suffix is - ̈̈ which is rather rare in contemporary Slovak and occurs e.g. in žriebä 'colt'. It usually denotes the young of an animal, but can also be found in several other words, e.g. púpä $\left(_{\text {poet. }}\right.$ bud+DIM'). Historically, the suffix $-a$ and its variant $-\ddot{a}$ stem from OCS $-E_{\varepsilon}$, e.g. žrěbĘ 'colt', ovbčĘ 'lamb' [cf. Večerka 1984: 209].

41 As to the diminutive (or close-to-diminutive) suffixation resulting in derivatives of one gender, in this case neuter, regardless of the gender of their base, the suffix $-a$ is crosslinguistically interestingly analogous to the French diminutive suffix -eau which is -by Stump [1993: 2] denoted as "not transparent with respect to gender", as its derivatives are "uniformly masculine, regardless of the gender of their base", and he gives the examples chèvre $\mathrm{F}$ 'goat' - chevreau M 'kid', souris F 'mouse' - souriceau M 'small mouse', $\mathrm{F}$ tonne 'cask' - M tonneau 'keg'. Of course, the analogy only concerns the one-gender result of derivation, as full analogy with Slovak cannot occur because of the different number of genders in both cases, Slovak also having Neuter.

Cross-linguistically it can also be remarked that suffixes borrowed into Slovak with foreign diminutivised words, e.g. -ulus, -idium,-ina, which for English are by some linguists included in the number of diminutive suffixes, are not considered for diminutive suffixes in contemporary Slovak, the reason being that they were never productive, hence the Slovak inventory of diminutive suffixes only entails domestic, i.e. Slavic derivative morphs.

With regard to English, some authors include in the number of diminutive suffixes also two suffixes of Slavic origin, -chik and -sky listed by Galinsky [1952; in: Schneider 2003: 79] as diminutively used in American English. However, it has to be pointed out that while -chik is the masculine form of the basic e.g. Russian diminutive suffix, having its corresponding forms in other Slavic languages, too, cf. Slovak -čik, the supposedly diminutive suffix -sky must have undergone what evidently seems as a semantic shift of misinterpretation, because in Russian, Slovak, Czech, Polish, as well as other Slavic languages it is a suffix forming adjectival derivatives which are in no way related to diminutives, cf. e.g. Slovak hora 'mountain' $\rightarrow$ horský 'mountainous', cisár 'emperor' $\rightarrow$ cisársky 'imperial', svet 'world' $\rightarrow$ svetský 'worldly', Dunaj 'the Danube' $\rightarrow$ dunajský 'Danubian' [cf. Horecký 171: 173 - 177]. Of course, cross-linguistic semantic shifts, even if contradicting the meaning and/or functionality, in this case lexico-grammatical, of the linguistic element in the source language, are a legitimate way of extending the lexis.

\subsubsection{Gradability of Diminutivised Substantives}

In Slovak, similarly to other Slavic languages, multiple degrees of diminutiveness or gradability of diminutives occurs. Furdík [2004: 90] refers to such process by the term "repeated diminutivisation". Chamonikolasová and Rambousek [2007: 38] dealing with such multiple nominal diminutive derivatives in Czech refer to them as first-grade and second-grade, or Grade 1 and Grade 2 diminutives, and we will use the latter terms. Such graded diminutive derivation is expressed by the diminutive suffixes of the 
particular grade, or a sequence of two different diminutive suffixes attached to the base.

Gradable substantives can primarily express small size, and can morphologically be exemplified by the following Table 2 :

Table 2: Gradability of substantives

\begin{tabular}{|l|l|l|l|}
\hline Gender & Base & Grade 1 & Grade 2 \\
\hline M & syn 'son' & synček & synáčik \\
\hline & nôž 'knife' & nožík & nožiček \\
\hline & kvet 'flower' & kvietok & kvietoček \\
\hline F & hlas 'voice' & hlások & hlásoček \\
\hline & loĎ 'boat' & loĎka & lodička \\
\hline & hora 'mountain' & hôrka & horička \\
\hline N & hlava 'head' & hlávka & hlavička \\
\hline & slovo 'word' & slovko & slovićko \\
\hline & telo 'body' & tielko & telićcko \\
\hline & víno 'wine' & vínko & vínečko \\
\hline
\end{tabular}

In general, Grade 1 diminutives are more frequent than Grade 2 ones, both in langue and parole, they have a higher rate of becoming desemantized ('frozen') than the second-degree diminutives, and a lower rate of becoming expressive, though potentially also entailing expressivity.

However, in Standard Slovak not all generic nominal diminutives are gradable, i.e. they can only form Grade 1 diminutives, e.g. brat 'brother' - bratček, strom 'tree' - stromček, ulica 'street' - ulička, pole 'field' - polićcko, lavica 'bench' - lavička, (though, within ad-hoc formation, colloquial, familiar or child-use or child-oriented language forms like lavicôčka could also occur).

Some substantives (in all or some of their meanings) synchronically have Grade 1 as their 'frozen diminutive' basic form, e.g. fialka 'violet' (though fiala does exist, it is either a plant of a different species, or a very rarely used synonym of fialka). In some cases the substantive does not have Grade 1, only Grade 2 as directly semantically related to the base, e.g. voda 'water' - vodička. Though Grade 1 formally exists in vodka, it has become a 'frozen', i.e. a desemantized diminutive and, as a result of split of polysemy, became an autonomous lexeme.

The morphs used for Grade 1 and Grade 2 diminutivisation are not fully differentiated. While -ik/-ik, -ok, *-ec, -ka, -ko are means of Grade 1 diminutivisation, the remaining suffixes either form Grade 2, or they are used as the only suffixes which can 
diminutivise the particular substantive, hence as means of Grade 1, e.g. syn 'son' synček, izba 'room' - izbička, pole 'field' - polićko, etc.

The existing constraints on the gradability of substantival diminutiveness are basically conventionally conditioned, i.e. systemically non-predictable, but such evaluative suffixal derivation is relatively open.

Though Czech and Slovak are closely related Slavic languages, there occur differences between them e.g. also in the set of diminutive affixes and in the diminutive derivability of substantives. Gladkova [forthcoming] points out that in Czech there do not exist any analogous expressive diminutives to e.g. the Slovak bicyklik 'bicycle+DIM', chlebik 'bread+DIM' or rốík 'year+DIM'. We could add that in Czech from e.g. zajíc 'hare' there also does not exist any Grade 1 diminutive that would be analogous to the Slovak derivative diminutive zajko.

Gradability, with partly different suffixes, also occurs with hypocoristic references to family members, e.g.:

\begin{tabular}{|l|l|} 
(1) & mama 'mother' - mamka/manina - maminka/mamička - ${ }_{\text {familiar }}$ mamuL'ka - mamulienka/mamičenka \\
\hline & otec 'father' - ocko- ocinko/ocino - ${ }_{\text {familiar }}$ ocuL'ko/oculík \\
\hline
\end{tabular}

53 The gradability of these words, similarly to the gradability of some first names, considerably exceeds the otherwise typical two grades, allowing for both variety and personalized usage of intensified affectionate address. Fewer derivative exist in the case of e.g.:

(2)

dedo 'grandfather' - dedko - deduško (both diminutivised with neuter suffixes but the derivative is masculine)

babka 'grandmother' - babička.

54 Of cross-linguistic interest is the fact that according some authors [cf. Dressler and Merlini Barbaressi 1994: 114] also in English (hence not only e.g. in Slavic languages, including Slovak) there exists gradability, referred to in the above source as recursiveness, and they give examples from Quirk et al. [1985: 1584] as fatso, momsiely, footsie, shoesies. However, in spite of such occurrences it can be stated that in general recursive or graded diminutivisation is much more marginal in English than in Slovak where, moreover, it is used with adjectives and adverbs, too (see 4.2).

Similarly to a number of other languages, diminutivisation in Slovak also concerns the special onomasionogical category of first names. Though first names derived by formally diminutive suffixes semantically do not fall into the category of quantitative evaluation, traditionally and in fact internationally they tend to be included in the number of diminutivised lexical units, which is the case both of English [cf. Schneider 2003] and Slovak. This also proves the semantic closeness and potential and/or partial overlapping of the category of diminutives and the category of hypocoristics.

In Slovak, the variants of diminutives of first names (in the function of hypocoristics or endearments), including also the graded variants, occur with most first names, the 
range of the diminutive affixes exceeding the substantival diminutivising affixes which are often extended by creating idiolect ad-hoc formations or familiarisms within the systemically present potential onomatological patterns. Typically, first names in Slovak form two grades, with increasing intensity of expressivity and endearment.

In general we can state that in the case of some first names diminutivisation and the sequences of graded hypocoristic diminutives can be more extensive with female names than with masculine ones. This also applies for their pragmatic occurrence. While outside the environment of family or friends the unmarked usage of Grade 2 of male diminutive names is actually nearly excluded (except in ironical, jocular or otherwise communicatively marked contexts), with feminine names it is quite frequent.

The diminutivised first names as hypocoristics, including the informal truncated variants and their gradability in Slovak could be exemplified by the following forms:

(3) Peter/Peřo - Petrik/Peřko - Petríčk/Petinko/PeřuLko/Peřulik

Jana - Janka - Janička/Janinka/JanuL'ka/Januška - Janulienka/Januliatko

In idiolect, within a family or friendly environment, the generally used patterns of diminutivisation of first names can be extended by ad-hoc formations.

In Slovak diminutivised first names are used with family members, friends, among colleagues, in general in informal environments which usually allow for analogous diminutized endearments also in other languages, though some of their pragmatic characteristics are more specific. Most frequently, diminutivised first names are used in addressing children, or by children addressing children or adults, and with family members or friends, though they tend to be more frequent when addressing women than men. When addressing above all men they can also be used ironically or with disdain (then usually Grade 2 is used, e.g. Jožinko from the sequence Jozef/Jožo - Jožko Jožinko).

61 It is interesting to note that in some regions and dialects of Slovakia in certain types of polite address non-diminutivised first names are used, but they are preceded by a diminutivised generic substantive denoting a relative, e.g. tetka Eva 'aunt+DIM Eve', ujko/ ujček Jano 'uncle+DIM John'.

In the case of some names the diminutivised form of the name (usually feminine) can (as a variant of the basic name) be officially registered at birth, hence a baby can be registered e.g. as Jana or Janka, though the latter is less frequent and the number of names with already diminutivised base forms is very low.

In spite of the wide systemic occurrence of diminutivisation of first names, some do not form diminutives, e.g. František 'Francis', probably because of the presence of the final sequence -ek which is formally identical with the diminutive suffix, and even preceded by the palatalized sibilant $-\check{s}$, and, consequently, only its truncated form Fero is diminutivised into Ferko. In the case of e.g. Marek no such constraint applies and it gets diminutivised as Mareček. Some foreign first names are usually not diminutivised, e.g. Henry, Hugo, René. 


\subsubsection{Notes on Lexical-Semantic Distribution and Pragmatic Functions of Suffixal Substantival Diminutives}

64 Though suffixal diminutivisation of substantives is a nearly unlimited word-formative process in Slovak, and in general the formation of diminutives is productive and its frequency high, there are also several areas where diminutives are rather infrequent, depending not only on their semantic content, but also on the communicative intention and pragmatic context. As their range and complex variety is beyond the scope of this paper, we shall present here only several observations concerning their distribution many of which are known to occur or can be expected to occur in other languages, too, while the occurrence of others is more specific.

of course, diminutivisation in Slovak occurs above all in any naming units where small size needs to be expressed, i.e. concrete substantives denoting material phenomena, e.g. domček 'house+dim', dvierka 'door+DIM', ulička 'street+DIM', animals, especially pets, where regardless of the size of the animals the words can become endearments, e.g. mačička 'kitten', konik 'horse+DIM', muška 'fly+DIM', slonik 'elephant+DIM', plants, e.g. stromček 'tree+DIM', klinček 'small metallic, etc. nail; carnation', in the latter case (also) as desemantized 'frozen' diminutive, and in many other thematic areas.

Although 'frozen', i.e. lexicalized, and as to expressing small size desemantized derivatives with diminutive suffixes, do not constitute the target of our research, several notes will be devoted to them. Among diminutivised and 'frozen' suffixal derivatives in Slovak there is a variety of lexical units, some of them thematically classifiable, e.g. certain names of flowers and plants, e.g. the above fialka 'violet', klinček 'carnation', several anatomical references, e.g. maličck 'index finger' or jablčko 'Adam's apple; kneecap', etc. The number of morphologically diminutivised anatomical naming units also includes the Slovak equivalent of the term for 'pupil (of the eye)' which in Universal \# 1176 (originally \# 1180) is on the basis of 118 languages of worldwide distribution presented as "most likely to be derived from substantives denoting a small human like a baby, or a child, or a diminutive humanlike object like a doll." In compliance with this universal the Slovak equivalent can be diminutive, i.e. zrenička, but does not have to be a diminutive, cf. zrenica, though in non-terminological usage the diminutive form prevails. However, what is quite different is the motivation. In slovak the naming unit is not motivated by a small human or humanlike object, but by the verbal base zrieř 'to see' (as a verb it mostly occurs with prefixes: pozrieř 'to look', zazrieř 'to notice', prezrieř 'to check', etc.), similarly to the motivation of the Czech nondiminutivised zrítelnice or zornice, or diminutivised zornička. In contrast to Slovak, Czech also has the morphologically diminutive panenka (literally 'little doll') and the Latinate pupila, both fully testifying to the statement made in the above universal. However, on the whole it is generally stated that Slovak has more 'frozen' diminutives than Czech, though such claim will have to be proved or disproved by further researchof the data.

An area where diminutivised substantives tend to occur in Slovak is in the jargon of drug abusers, where they express their positive attitude to the denoted phenomena, or even endearment, e.g. f'́aštička 'bottle', pohárik 'glass', vínko/vínečko 'wine', maryška 'marihuana', though with the exception of the latter word the above diminutives are also part of the general vocabulary as informal, jocular or even polite offer or request references (see later). 
area that to our knowledge does not get mentioned in Slovak linguistic sources and research at all is the usage of generic diminutives as means of the politeness maxim. E. g. in restaurants and services in general there is a tendency to diminutivise some of the generic substantives referring to what is offered or provided. Hence, while a waiter's question Dáte si kávu? 'Would you like coffee?' or Prinesiem vám kávu? 'Shall I bring you coffee?' is polite, but expressively neutral, Dáte si/Prinesiem vám kávičku? or even only Kávičku? 'coffee+DIM', in the Accusative Singular, as required by the verb, though the verb is elided) are not only less formal but even more kind, showing in a more personal way the willingness to offer the service. Such diminutives are often used as references to drinks, e.g. also čajíček, pivko, vínko, to food, e.g. polievočku, gulášik, etc. They are also frequent in comunication in family, among friends, to guests, and, above all to children, e.g. Chceš mliečko? 'Would you like milk?', or kakauko 'cocoa', mäsko 'meat', koláčik 'cake', etc. Similarly, also e.g. in a hospital the nurse could ask: Prinesiem Vám vodičku? 'Shall I bring you water?', the diminutive showing both willingness and compassion. Subsequently, the diminutive tends to be used also in the answer.

71 Diminutives as expressions of politeness also occur in references to parts of the body, e.g. a hairdresser would diminutivise hlava 'head' into hlavička when asking her customer: Zohnite hlavičku! 'Would you bend your head?', or e.g. to items offered or considered for purchasing, e.g. an assistant in a clothes store could ask: Vyskúšate si tento kabátik? 'Would you like to try this coat on?', with diminutivised kabátik 'coat+DIM'. In Slovak, suffixal diminutivisation tends to be used also in compliments or appreciative statements, usually to women or children. Hence, e.g. in reference to klobúk 'hat' the common compliment would be: Máte krásny klobúčik! 'What a lovely hat you've got!', with the diminutivised klobúčik. Suffixal diminutives also occur when patience is politely asked for explicitly, e.g. Počkajte chví́ku/chvíLočku! 'Would you wait for a while!', or implied within a statement 0 minútku/minútočku prídem 'I will be back in a minute'. However, the latter is not a phenomenon with wide lexical diffusion as also for semantic reasons not all time-references get derivatively diminutivised in such communicative situations; while diminutivised are hodinka 'hour+DIM', dníček 'day+DIM', rôčik 'year', no diminutivisation occurs e.g. in the case of *mesiačik, probably also because of its being homonymous to the expressive diminutivised word meaning moon. 
72 As pointed out by a number of authors [cf. in Schneider 2003: 164], diminutivisation in requests, offers, suggestions, asking for patience and in various communicative strategies exists also in other languages. Their pragmatic typology in English is in detail analyzed by Schneider [2003: 164-235]. However, for these communicative functions many languages, including English, use only or prevailingly lexical analytical diminutivisation, not suffixal as Slovak does.

When returning to the above communicative situation in services, in Slovak diminutivisation of addressing the attendants or the customers is not used. Actually, when e.g. a speaker of Russian visiting Slovakia addresses the attendant ДЕвУшкА 'girl+ DIM', which in Russian is appropriate (while the parallelly existing Russian ДЕвочКА is a diminutive per se and is not used in such situations), to the Slovak attendant (who does not happen to know Russian well enough, but due to partial mutual comprehensibility understands the word itself) the address sounds very inappropriate or even rude. Similarly, also some of the Roma, who like in many other European countries constitute an ethnic minority in Slovakia, tend to address strangers as panička 'Missis+ DIM', pánko 'Mister+ DIM', where to Slovaks the diminutivisation of these lexical units sounds inappropriate, imposing or ironical. However, this is interference from the Romani language where such diminutivisation is appropriate and expresses polite address and request, the corresponding diminutive forms in Romani being rajoro (raj 'Mister+ DIM') and raňori (raňi 'Missis+ DIM'). This testifies to a different lexical and pragmatic distribution of hypocoristic diminutivisation in both languages.

In Slovak suffixally diminutivised generic address is appropriate e.g. in the cases of address used by children to adults, i.e. ujko (literally 'uncle+DIM') or tetuška (literally 'aunt+DIM') which (together with the non-diminutivised teta) in this function became common and standard. Similarly, when addressing a child the name of which we do not know, in Slovak we use diminutive forms, i.e. dievčatko 'girl+DIM' and chlapček 'boy+DIM). Similarly, slečinka (slečna 'Miss+DIM') is also used, though getting slightly dated, and is typically used by older people. It can be used jocularly or flatteringly as well, including addressing little girls, but also ironically, expressing critical attitude or disdain.

Similarly to many other languages, potentially high in Slovak is the occurrence of diminutives in literature for children, in poetry and in lyrical prose, though in contrast to some other languages the diminutives are suffixal derivatives. Though typically much higher than in non-Slavic languages, their number and frequency of usage depends on the literary or poetical crede of the author, as well as on the literary period, etc. In the poetry of Slovak romanticists, e.g. by Janko KráL' (1822-1876), diminutives are very frequent, while e.g. in the poems written by contemporary writers they are not so numerous. Still, e.g. in the humanistic poetry whose author is the Slovak poet Milan Rúfus (1928-2009), several times nominated for the Nobel Prize, we can find on average at least one diminutive per poem, though his poetry is certainly not oversentimental. Regardless of the personal preferences, genre, theme, etc., diminutives in Slovak are extensively used and perceived as potential expressive and - in appropriate contexts favoured tools of the belles lettres.

With regard to the range of pragmatic functions of diminutives, as pointed out by Rončáková [2009: 126], in Slovak diminutivisation can also be used as one of the typical manifestations of pathetization of the text. She indicates that diminutives in this 
function occur above all in religious songs and folk variants of prayers, e.g. dietky Božie 'Lord's children+DIM'.

of course, too many diminutives in Slovak utterances can sound inappropriate and oversentimentalizing. Moreover, at present mainly among young people, as part of post-positive communicative attitudes, there can be perceived a tendency at reducing their number in utterances and texts (in all their word-class forms). Hence, among young people (with the possible exception of very affectionate relationships), e.g. the preferred address to friends is often not a diminutive of the first name but its truncated form or a nickname. To some extent the above attitude has also led e.g. to the revaluation of mamka 'mother+ DIM' which several decades ago was perceived primarily as a diminutive, but at present it is mostly used as a relatively neutral, informal or even slightly impolite and usually only indirect reference to mother, though in idiolects or in dialectal usage it continues to function as an endearment. It has to be noted that the partly reserved attitude of some young speakers of Slovak to diminutives is not a result of some cross-linguistic influence, but a certain (possibly cross-cultural) change of attitude in communication which could be characterized as aiming at desentimentalization. Though such changing attitudes have their impact on the linguistic behaviour, in general this does not diminish the high frequency and functionality of diminutives in other spheres of usage.

Diminutivised words (in all word-categories) can pragmatically also be used as negative evaluation, expressing that some phenomenon, feature, circumstance, etc. does not come up to the expected quantity, quality, etc., hence is intended and/or perceived as expressing insufficiency, inadequacy, inappropriateness, and consequently can even become pejorative within irony, disdain, ridicule and similar negative attitudes. Gladkova [forthcoming] points out that negative evaluation occurs exclusively only with masculine diminutives, and gives the example úradnićek 'úradnik + DIM' with the meaning 'unqualified, inefficient, etc. office worker'. In addition, as a result of the presence of the particular prosodic features, actually any (autosemantic) words, hence also the diminutivised ones, can potentially express negative attitudes, and due to the possibility of expressing e.g. inadequacy, derivative diminutives offer theselves as candidates for this semantic-pragmatic shift. In English an analogous shift of attitudinal polarity could also be found in the case of derivatives with e.g. the suffix ette or -ling.

\subsection{Suffixal Adjectival and Adverbial Diminutives}

Slovak adjectival and adverbial diminutives share a number of morphological features, hence are presented here jointly.

Diminutive adjectives and adverbs are mostly formed with the suffixes represented in the following Table 3 together with some examples, in relevant cases also with Grade 2 diminutive formations:

Table 3: Graded Diminutive Adjectives and Adverbs

\begin{tabular}{|l|l|l|l|l|l|}
\hline Adjective & $\begin{array}{l}\text { Diminutive Suffix \& } \\
\text { Derivative }\end{array}$ & Adverb & $\begin{array}{l}\text { Diminutive Suffix \& } \\
\text { Derivative }\end{array}$ & \\
\hline
\end{tabular}




\begin{tabular}{|c|c|c|c|c|c|}
\hline Base & Grade 1 & Grade 2 & Base & Grade 1 & Grade 2 \\
\hline & -ičký/-inký & -ilinký & & -ičko/-inko & -ilinko \\
\hline malý 'small' & maličký/-inký & malilinký & málo & máličko/-inko & málilinko \\
\hline \multirow[t]{2}{*}{ pomalý 'slow' } & pomaličký/-inký & pomalilinký & pomaly & pomaličky/-linky & pomalilinko \\
\hline & -učký/-unký & -ulinký & & -učko/-unko & -ulinko \\
\hline bledý 'pale' & bledučký & -bledulinký & bledo & bledučko & bledulinko \\
\hline dobrý 'good' & $\begin{array}{l}\text { dobručký/ } \\
\text {-unký }\end{array}$ & dobrulinký & dobre & dobručko & dobrulinko \\
\hline milý 'kind' & milučký & milulinký & milo & milučko & milulinko \\
\hline mladý 'young' & mladučký & mladulinký & mlado & mladučko & mladulinko \\
\hline sladký 'sweet' & sladučký & sladulinký & sladko & sladučko & sladulinko \\
\hline starý 'old' & staručký & starulinký & staro & staručko & starulinko \\
\hline $\begin{array}{l}\text { voňavý 'smelling } \\
\text { nicely' }\end{array}$ & voňavučký & --- & voňavo & voňavučko & $\mid--$ \\
\hline
\end{tabular}

The majority of masculine adjectives are diminutivised with the suffixes -ucký/-unký in Grade 1 (or primary derivation) and -ulinký in Grade 2 (or secondary derivation), and the majority of adverbs are diminutivised with -učko/-unko in Grade 1 and -ulinko in Grade 2. Hence the morph -li- participates in forming Grade 2, but within repetition also other Grades, e.g. from maly' 'small' in expressive utterances we can even find malilililinký, above all in familiar and colloquial language, in the speech of and to children, in idiolect and in ad-hoc formations, sometimes even with less frequent variant morphs, cf. malilinkatý (with positive connotations).

In Slovak due to concord adjectives in their basic or any other forms adopt the grammatical categories of the head substantive, though they follow their own adjectival declension paradigms. The above Table 4 gives their basic, i.e. nominative singular masculine form, while the corresponding feminine forms end in -á, i.e. malá maličká - malilinká and neuter forms in -é, i.e. malé - maličké/malinké - malilinké.

Derivative diminutive adjectives and adverbs are formed above all from qualitative adjectives (pekný 'nice' - peknučký) and adverbs (pekne 'nicely' - peknučko) and several other semantic types expressing subjective, e.g. quantitative evaluation (maly' 'small' malický) or qualitative evaluation (mily 'kind' - milučký). As far as we know, there has not not been carried out any research into the semantic typology of Slovak adjectives and adverbs allowing for evaluative gradeability, but from our data it seems that adjectives and adverbs with a semantically primarily positive and consequently thus also usable and perceivable content prevail (cf. the above list). Still, diminutivisation can also occur with adjectives with negative semantic content used with compassion or (usually only) mild irony, e.g. 
\begin{tabular}{|l|l|} 
(4) & hlúpy ‘silly' - hlúpučký \\
\hline & tučný 'fat' - tučnučký
\end{tabular} semantic relevance of the base (e.g. ?unavenuck ký) they could occur in child or childrelated speech.

However, just like in the case of other lexical units, any suffixally diminutivised adjective or adverb can, in certain pragmatic contexts, be also used ironically or can express disdain or negative attitude.

the case of some adjectives and the analogous adverbs, due to so-far not specified semantic reasons, their diminutivising derivability is rather improbable, though not necessarily completely impossible, e.g.:

\begin{tabular}{|l|l|}
\hline (5) & bohatý 'rich' - ?bohatučký \\
\hline & rýchly quick' - ?rýchlučký \\
\hline & silný 'strong' - ?silnučký \\
\hline & unavený 'tired' - ?unavenučký \\
\hline & usilovný 'dilligent' - ?usilovnučký \\
\hline
\end{tabular}

Their ad-hoc communicative occurrence would tend to be ironical or, in the case of the As evident from Table 3 above, some diminutivised adjectives and adverbs do not have any Grade 2 derivative, but to our knowledge the constraints on their formation have not yet been treated in available Slovak linguistic sources.

\subsubsection{Collocability of Suffixally Diminutivised Evaluative Substantives with Diminutivised Adjectives}

When small size is expressed in Slovak by a semantically inherently diminutive, i.e. morphologically non-diminutivised adjective followed by a non-diminutivised substantive, e.g. malý dom 'small house', the collocation does not carry any expressivity. Grade 1 diminutivised adjective collocated with non-diminutivised substantive, e g. maličký dom, also tends to be neutral, basically entailing the intensifying seme, hence meaning 'very or considerably small house', but can potentially/situationally acquire positive expressivity, though a negative one is communicatively not excluded either. The other collocations given sub c) below entail the expressivity of primarily positive evaluation, i.e.:

\begin{tabular}{|l|l|l|}
\hline (6) & a) Non-expressive: & malý dom \\
\hline & b) Usually non-expressive: & maličký dom \\
\hline & c) Expressive: & malý domček - maličký domček - malilinký domček \\
\hline
\end{tabular}


In the latter two expressions there occurs the concord or harmony of morphological derivative diminutivisation of the adjective and the substantive, which is not obligatory, though communicatively it is highly probable. At the same time, this is multiple diminutivisation, suffixally present both in the adjective and the substantive, with the intensification of small size and typically also with increased expressivity. In e.g. fairy-tales even the co-occurrence of a Grade 2 adjective with a Grade 2 substantive could be found, e.g. malilinký domčúrik.

\subsection{Diminutivised Verbs}

In Slovak also verbs can be diminutivised. They are formed by the morph $-k$, with its rarely occurring variant -ink-, added to the base before the grammatical morph, the word-formative process sometimes being accompanied by the modification of the base. In general the thus diminutivised verbs carry the meaning of lower intensity of the action or process. We suggest their following semantic-pragmatic classification depending on their meaning and/or usage:

\begin{tabular}{|c|c|c|}
\hline (7) & 1. & low intensity per se: \\
\hline & & hrabaŤ ‘rake' $\rightarrow$ hrabkaŤ, škrabaŤ ‘scratch' $\rightarrow$ škrabkař \\
\hline & 2. & low intensity and repetitiveness: \\
\hline & & 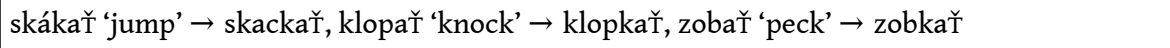 \\
\hline & 3. & $\begin{array}{l}\text { leisureliness or comfortableness of the action, process, or state and/or usage in child or } \\
\text { child-oriented language: }\end{array}$ \\
\hline & & ležaŤ 'llie' $\rightarrow$ ležkař, hraŤ sa 'play' $\rightarrow$ hrajkaŤ sa, spaŤ ‘sleep' $\rightarrow$ spinkaŤ \\
\hline & 4. & usage in child or child-oriented language \\
\hline & & beža ̌ 'run' $\rightarrow$ bežkaŤ, plakaŤ ‘cry/weep' $\rightarrow$ plačkaŤ \\
\hline & 5. & $\begin{array}{l}\text { usage in child or child-oriented language with exclusively child or child-oriented verbal } \\
\text { bases: }\end{array}$ \\
\hline & & $\begin{array}{l}\text { papař 'eat' } \rightarrow \text { papkař, hajař 'sleep' } \rightarrow \text { hajkaŤ, búvař 'sleep' } \rightarrow \text { buvinkaŤ, hačař (si) 'sit } \\
(\text { down)' } \rightarrow \text { hačkaŤ (si) }\end{array}$ \\
\hline & 6. & $\begin{array}{l}\text { usage in child or child-oriented language, but also in affectionate communication among } \\
\text { adults or in polite requests: }\end{array}$ \\
\hline & & L'ahnúŤ si ‘lie down' $\rightarrow$ L’ažkaŤ si, sadnúǐ si ‘sit down’ $\rightarrow$ sadkaŤ si \\
\hline
\end{tabular}

91 The classes suggested do not have distinct boundaries and are marked by possible overlaps, e.g. Class 1 potentially also entails the seme "repetitiveness", i e. a category of verbal action which is specific for Class 2. 
Some verbs, though containing the morph $-k$ - and formally diminutive, do not synchronically have any lexically autonomous basis, e.g. čačkař 'to overdecorate', drankař 'to ask for something in an insisting way', brnkař 'to play on a string instrument', šepkař 'to whisper', etc.

Though verbs containing the diminutive morph can also occur as stylistically unmarked lexical units, they are mostly used in expressive function or in the above outlined communicative registers. Specific is the case of polite request. In Slovak a host/hostess can suggest to the guest: Sadkajte si! 'Would you like to sit down?/Sit down, please', where the verb sadnúŤ si 'to sit down' gets derivatively diminutivised, or a nurse can politely and caringly ask the patient: Lažkajte si! 'Would you lie down, please?', diminutivising the verb L'ahnúŤ si 'to lie down'.

94 Though above all in child and child-oriented language suffixal diminutivised verbs are very frequent, their overall systemic and communicative status is relatively low. Only a relatively small number of verbs has been lexicalized as diminutivised.

Also diminutivised verbs are an open lexical set, readily extended within ad-hoc formations and/or idiolect usage. Thus, in family of friendly communication e.g. robka Ť (from robiř 'to do+ DIM') can be used, e.g. Čo robkáte? 'What are you/have you been doing', which sounds affectionate, can be slightly jocular, though can also be perceived as slightly dated or effeminate. However, the number of codified diminutivised verbs and theproductivity of their rise within ad-hoc formations is much lower than the diminutivisation of substantives, adjectives and adverbs.

\subsection{Suffixal Diminutives in Other Word Categories}

Very few suffixal diminutive derivatives can be found outside the word categories of substantives, adjectives, adverbs and verbs.

In the category of pronouns we have only found the familiar diminutive forms mojko and mojček derived from the possessive pronoun môj 'my, mine' within its nominalization, hence this diminutivisation is class-changing. These de-pronominal diminutives can be used as affectionate address to a child or a very close person. Similarly, the pronoun môj can also give rise to the diminutive derivative verb mojkař sa 'to cuddle', with the same communicative distribution (with no non-diminutive verbal base).

Though numerals themseves cannot be diminutivized in Slovak, substantivized numerals can marginally, in colloquial speech, become diminutivized. E.g. with regard to school results diminutives like dvoječka 'grade 2+DIM' occur, or some numeric references, above all amounts of money can be diminutivized, e.g. stovečka 'one hundred+DIM. However, this indirect diminutivisation of former diminutives has a small lexical diffusion, textual frequency and is substandard.

In the category of interjections we have identified only several diminutives and they can be classified as follows:

\begin{tabular}{|l|l|l|}
\hline (8) & $\begin{array}{l}\text { 1) } \\
\text { volitional: }\end{array}$ & $\begin{array}{l}\text { a) informal greetings: Ahojko! Ahojček! Čauko! 'Hi!/Bye!', Dobré ránko! 'Good } \\
\text { morning! }\end{array}$ \\
\hline
\end{tabular} 
b) imperative: Tísko! 'Silence, please!, Hush!'

2) vocative from a dated vocative form: Pánečku! ‘Gee!; literally 'Lordie!'

However, it has to be noted that some of these interjections are actually substantival diminutives (ránko, pánečku), while čauko and tî́sko are grammatically/formally identifiable with neuter substantives the most common word-formative pattern of which has is systemically marked by the suffix $-o$. With the possible exception of Tišsko! all of the above are colloquial diminutives.

101 Not many more cases of the occurrence of diminutivising derivation exist in these word-categories, hence diminutivisation in them is systemically and communicatively extremely marginal, though theoretically certainly of interest, also with regard to cross-linguistic comparisons of the possibilities of the existence of diminutivisation in other languages.

\section{Suffixal Augmentatives}

102 In Slovak suffixal augmentatives can be formed from substantives, adjectives and adverbs, though the productivity of their formation is relatively limited. In contrast to diminutives, they are always expressive.

\subsection{Suffixal Substantival Augmentatives}

In the category of substantives suffixal augmentatives are formed by only one dominant suffix with two allomorphs, i.e. -isko/-sko. Historically, there also existed, and to some extent in dialects has been preserved, derivation by -ina, e.g. chlapina 'man+AUG ' for masculine substantives [cf. e.g. Furdík 2004: 90], and -izňa, e.g. babizňa 'woman+ AUG' for feminines [cf. Nábělková 2010].

Semantically, augmentatives express excessiveness and at the same time usually negative or derogatory evaluation, though, more rarely, some augmentatives in certain contexts can also express appreciative evaluation. The tendency at negative expressivity is caused by the fact that excessive quantity, size or extent tends to be presented and/or perceived as inapropriate, undesired.

Furdík [2004: 90] points out that the (suffixal) formation of augmentatives is limited, but no further specification is given. With regard to comparing the presence of expressivity in diminutives and augmentatives Furdík gives, on the one hand, the example of the diminutive psiček 'dog+DIM' which can be used as a reference to a small dog, or expressively as a dog of any size, and, on the other hand, the augmentative psisko 'dog+ AUG' which refers to a barking, wretched or in some other way negatively denoted dog of any size. In other words, exclusively augmentative usage of derivative augmentatives does not occur.

As stated by Horecký [1971: 168], augmentative derivatives formed from the bases of all the three genders result nearly exclusively in neuter, hence to this effect augmentative substantival derivation in Slovak is usually class-changing, only preserving the neuter, i.e.: 


\begin{tabular}{|l|l|l|}
\hline (9) & $\begin{array}{l}\text { from } \\
\text { Masculine: }\end{array}$ & $\begin{array}{l}\text { chlapisko 'man+ AUG', vojačisko 'soldier+ AUG', obrisko 'giant+ AUG', stromisko 'tree+ } \\
\text { AUG', mečisko 'sword+ AUG'; }\end{array}$ \\
\hline $\begin{array}{l}\text { from } \\
\text { Feminine: }\end{array}$ & rybisko 'fish+ AUG', dlanisko 'palm ${ }_{\text {of the hand }}{ }^{+}$AUG', kostisko 'bone+ AUG'; \\
\hline & from Neuter: & telisko 'body+ AUG', námestisko 'square ${ }_{\text {of a city, etc }}{ }^{+}$AUG', dievč(at)isko 'girl+ AUG'. \\
\hline
\end{tabular}

However, when the base is masculine, in Slovak in augmentative derivatives there also occurs oscillation between neuter and masculine, e.g. from $\mathrm{M} d u b \rightarrow \mathrm{M} / \mathrm{N}$ dubisko 'oak+

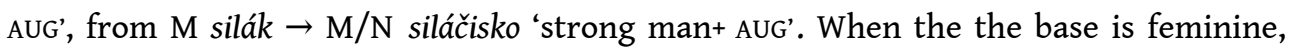
there is oscillation between neuter and feminine, e.g. from $\mathrm{F} b a b a \rightarrow \mathrm{F} / \mathrm{N}$ babisko 'coll., slightly vulg. woman+ AUG'. But, as pointed out by Nábělková [2010], in the case of animate masculine base the oscillation between genders fully concerns only the singular, in the nominative plural the neuter form tends to apply, i.e. chlapiská, siláčiská (not the forms with the corresponding masculine +HUM suffix -ovia). Nevertheless, this paradigmatic situation is neither transparent nor stable, and probably also depends on regional usage. In an older research Jánošík [1947/48; in Nábělková] found that the neuter prevails in Central slovak dialects, the natural gender in the rest of Slovakia, the latter with a tendency to influence also Central Slovak. Also (but not only) in this connection Nábělková [2010] observes a certain non-stability of the current norm, as well as a lack of any detailed analysis of this area of the Slovak lexis.

It is noteworthy that from some declension patterns no suffixal augmentatives are formed. Horecký [1971: 168] in this context points out sluha 'servant' and ulica 'street', the constraints being caused by the grammatical paradigmatic type.

As the majority of augmentatives is used in spoken language, their research is hampered by the lack of written data, and hence also their lower occurrence in the Slovak National Corpus. Moreover, many of those augmentatives which are included into it are from older literary texts or texts for children, and thus are either dated or communicatively specific.

\subsection{Communicative-Pragmatic Functions of Suffixal Substantival Augmentatives}

110 Slovak augmentative substantives are prevailingly used as expressive means of negative evaluation, though, as documented in the previous section, they can also be used positively, and in the case of several augmentatives the positive usage prevails. These possibilities could be presented as follows:

Negative evaluation expresses:

- inappropriate, excessive or unpleasant size, looks, etc.: domisko 'house+AUG', klobúčisko 'hat+ AUG';

- higher level of negative qualities, e.g. vulgar, wretched, vicious, rough, evil, etc.: čertisko 'devil+AUG', lotrisko 'coundrel+AUG';

- higher level of negative qualities perceived as threatening, cruel, dangerous, etc.: medvedisko 'bear+AUG', vetrisko 'wind+AUG'. 
Positive evaluation:

- appreciation, often accompanied by appreciative adjectives: (poriadny) chlapisko 'a really big/ strong man', (veL'ký) dobráčisko 'a really good/kind man';

- compassion: chudáčisko 'poor thing'.

111 Any other conditions of the lexical-semantic and collocation-based distribution of appreciative usage of suffixal augmentatives could only be specified by further research.

\subsection{Slovak Suffixal Augmentative Adjectives and Adverbs}

They are mostly formed only from adjectives and adverbs expressing large size, large extent or some extremely bad feature or circumstance. With both adjectives and adverbs the augmentative suffix is mostly -ánsky, which is a case of cross-categorial ('cross-class') homonymy of the derivative morph; for adjectives marginally also the suffix -izný and for adverbs rarely -izne is used.

113 Some examples of Slovak augmentative adjectives and adverbs are given in the following Table 4:

Table 4: Augmentative adjectives and adverbs

\begin{tabular}{|l|l|l|}
\hline Base Form & Augmentative Adjective & Augmentative Adverb \\
\hline veL'ký 'large' & velikánsky/veličizný & velikánsky/veličizne \\
\hline obrovský 'huge' & obrovitánsky & obrovitánsky \\
\hline vysoký 'high, tall' & vysokánsky/vysočizný & vysokánsky/vysočizne \\
\hline široký 'wide' & širokánsky/širočizný & širokánsky/širočizne \\
\hline hlboký 'deep' & hlbokánsky/hlbočizný & hlbokánsky/hlbočizne \\
\hline hrozný 'horrible' & hrozitánsky & hrozitánsky \\
\hline ukrutný 'cruel' & ukrutánsky & ukrutánsky \\
\hline
\end{tabular}

114 Though ad-hoc formations of augmentatives do arise, in Standard Slovak the lexical units given in Table 4 represent nearly all the frequent augmentative adjectives and adverbs.

115 As stated above, augmentative adjectives or adverbs, in addition to expressing excessiveness, are all marked as being mostly negative, though pragmatically can also function as expressing appreciation, e.g.:

\begin{tabular}{|l|l|} 
(10) & velikánsky chlap 'impressively/admirably, etc., large man' \\
\hline & hlbokánsky hlas 'incredibly/wonderfully, etc., deep voice'.
\end{tabular} 
In these cases they express higher than average size, quality or feature which is perceived as worthy of admiration.

\subsection{Collocability of Suffixal Augmentative Adjectives and Substantives}

When collocating suffixal augmentative adjectives with substantives, the following systemic possibilities exist:

\begin{tabular}{|l|l|l|}
\hline (11) & velikánsky dom & 'huge house' \\
\hline & velikánsky domisko & 'huge house+AUG' \\
\hline
\end{tabular}

The potential suffixal augmentative derivability is much higher than the number of lexicalized augmentatives. This also results in the fact that in the cases when the substantive is not codified or common as an augmentative, augmentativeness tends to be expressed by the adjective and not by the substantive, which also excludes any augmentative concord, e.g. instead of hribisko there occurs velikánsky hrib 'huge+ AUG mushroom'.

\subsection{Communicative-Pragmatic Functions of Suffixal Augmentative Adjectives and Adverbs}

With regard to communicative distribution, as the primary spheres of the usage of suffixal augmentative adjectives and adverbs Nábělková [2010] delimits informal spoken utterances, fiction and subjectively marked journalistic genres. In this context she quotes Smiešková's [1956: 81] statement that “in Standard Slovak augmentative substantives and adjectives are much more rare than in the rural and spoken language... They are frequent mostly in folk literature..." In addition, Nábělková points out their recent occurrence in various texts in internet conversation and discussions, which we could link with exaggeration, i.e. hyperboly within the communicative strategy of dramatizing the utterances. As examples we could give: Bol to obrovitánsky úspech. 'It was a huge success', or Mali tam hrozitánsky horúco. 'It was horribly hot there'.

\section{Notes on the (Potential) Opposite Polarity of Diminutives and Augmentatives}

Diminutives and augmentatives (both lexical, i.e. analytically expressed and suffixal, i.e. derivational) are semantically primarily opposite with regard to expressing quantification, extent, feature, etc. However, the semantic and pragmaticcommunicative intention and effect can vary with the particular words or their usage, entailing quantitative and/or qualitative modification, and within qualitative modification various positive or negative (ameliorative or pejorative) meanings can be communicatively applied or foregrounded. The traditional premise is that what is small tends to be positively marked or perceived and, on the contrary, large phenomena tend 
to be negatively marked or perceived. Though this applies for the majority of the items and usages of both types of evaluative derivatives, as stated e.g. by Nábělková [2010], in concrete utterances both axes cross in various ways, which allows also for negative usage/meaning of diminutives and for positive usage/meaning of augmentatives.

The semantic shift of diminution and augmentation from quantitative evaluation to qualitative evaluation, as well as their shift to opposite polarity, are allowed by the "possibility of interpreting diminution and augmentation in affective rather than purely objective terms [Wierbzicka 1980: 55ff., Szymanek 1988: 106ff.; in Stump 1992: 1]." Diminutives and augmentatives as modificational derivatives form a specific pragmatically 'disposed' part of the wordstock "allowing to express personal attitudes, perception, feelings, emotions and evaluation by word-formative modification of the lexical units" [Nábělková 2010; cf. Dolník 1999]. As stated by Nábělková, "the positive and negative expressive features, by which modificational" (here we would prefer the term 'evaluative') "derivatives differ from the emotionally neutral naming units, i.e. tenderness, favour, liking," (added could also be compassion), "kindness, pleasantness, purposefulness, admiration vs. aversion, fear, animosity, disparagement, antipathy, contempt, ironization, etc., tend to vary according to the particular needs of expression, providing to the language users - however, within the implicitness of the actual content of expressivity - a communicatively important possibility of subjective expression."

Hence, suffixal diminutives and augmentatives are lexical units with potentially very high polysemy and varied pragmatic possibilities the objective research of which will require intensive analysis not only of their system but also usage.

\section{Iconicity}

With regard to diminutives and augmentatives, Universal \# 1926 (originally \# 1932) in Plank and Filimonova's The Universal's Archives postulates the presence of iconicity, stating:

There is an apparently universal iconic tendency in diminutives and augmentatives: diminutives tend to contain high front vowels, whereas augmentatives tend to contain high back vowels.

Though detailed analysis of iconicity was not aimed in this paper, as evident from the evaluative suffixal derivative morphs presented in the above sections, front as well as back vowels (high and low) occur in the set of both diminutive and augmentative derivative morphs used within the particular word-classes in Slovak, and though the consonant in some of the diminutive suffixes is palatalized (i.e. $-\check{c}_{-}$), non-palatalized consonants can occur both in diminutive and augmentative evaluative morphs, though in augmentative morphs only non-palatalized consonants occur. The above testifies to the finding of Štekauer et al. [2009: 127], based on the research of data from 25 languages, that the "postulate of phonetic iconicity in the domain has not been confirmed for European languages as a whole," and, as investigated by Körtvéyessy, the "phonetic iconicity has not been confirmed for ... African languages" [2010: ]. In their research Gregová and Panocová came to the conclusion that "the analysis of diminutive and augmentative affixes from 11 Slavonic languages failed to provide evidence for the Universal 1926" [2009: 49]. Our data support the above. 


\section{Conclusion}

The complex system of suffixal diminutivisation in Slovak, as characteristic of a inflectional (inflectional synthetic) language, its presence in a number of word-classes, as well as its high and nearly unlimited productivity in most of them can, in our opinion, be primarily ascribed to the fact that, similarly to the situation in other Slavic languages, all its means are native. This is also one of the reasons why it has a strong systemic status in Slovak evaluative morphology. Though there are a number of variant suffixes, their core is formed by the morph $-k$ - (and its palatalized variant $-\check{c}_{-}$), which makes the morphologial and onomatological component rather coherent and transparent, and this is deemed to contribute to the strong systemic presence of suffixal diminutivisation in Slovak. In addition to high productivity, which in diminutivizsation in most word-classes includes also gradability, suffixal diminutives have high textual occurrence, above all in the everyday language, in several registers and thematic areas, as well as a wide range of pragmatic functions. Some of them are analogous to those in other languages, but several are rather specific and not shared with diminutives or suffixal diminutives in other languages in general, and have been at least partly highlighted in the sections of this paper.

Although suffixal augmentative morphs also exist and function in Slovak, their wordclass distribution, systemic status and range of pragmatic functions is much weaker, most probably similarly to the situation in many other languages (in the case that aumentatives exist in them at all).

Though the system of evaluative quantitative morphology in Slovak is relatively stable, in line with the linguistically generally applying principle of dynamic stability it demonstrates several dynamic changes even within its most recent developments, as indicated by the differences currently occurring in the means, attitudes and usage of diminutives and augmentatives.

Expressing quantitativeness, i.e. size, quantity and extent, etc. is universal in languages, however, expressing them suffixally is more language-specific. In this respect our research has in some ways also testified to Bauer's statement that "there are still plenty of places to look for universals", and that "in those places where we have already looked, there are plenty of unconsidered possibilities" [2009: Košice Conference presentation]. We have attempted to look at some of them within the evaluative morphology of one of the thousands of the languages of the world - our native Slovak, but in spite of that, as we tend to hope, some of the findings concerning slovak can perhaps have their counterparts in universal contexts.

\section{Future Research}

The work on this paper on the theme of diminutives and augmentatives in Slovak has led us to identifying several of the possible tasks for future research:

- semantic and word-formative constraints on suffixal formation of diminutives and augmentatives;

- predictability of and constraints on gradability;

- systemic communicative range and pragmatic functions of diminutives and augmentatives;

- 'frozen diminutives', their inventory and analysis of their semantic content; 
- contrastive bi-lingual research of diminutives (and augmentatives);

- comparative research of diminutives (and augmentatives) in sets of genetically related languages;

- cross-linguistic identification of faux amis within diminutives (and augmentatives);

- textual occurrence, frequency and pragmatic functions;

- translatability and compensation procedures and strategies in cases of non-parallelism;

- analysis of lexicographical representation of evaluative morphs.

One of the main prerequisites for effectively dealing with these and other related tasks is a systemic collection of empirical data and their analysis not only on the basis of written texts, which ideally should be corpus-based or in contrastive studies parallelcorpus based, but above all their analysis on the basis of spoken discourse where the occurrence of evaluative morphs is much higher and semantically and pragmatically more varied than in written discourse.

\section{BIBLIOGRAPHY}

BAUER Laurie, English Word-Formation, Cambridge, Cambridge University Press, 1983.

BAUER Laurie, “No Phonetic Iconicity in Evaluative Morphology?", Studia Linguistica, Vol. 50, 1996: 189-206.

BAUER Laurie, "State of the Art in the Field of Word-Formation Universals", Paper presented at the International Conference Universals in Word-Formation, Košice, 2009.

BAUER Laurie, "Evaluative morphology: in search of universals", Studies in Language 21, 1997: 533-575.

BAUER Laurie, An Introduction to International Varieties of English, Edinburgh, Edinburgh University Press, 2002.

BÁzLIK Miroslav \& AMBRUS Patrik, A Grammar of Legal English. Bratislava, Iura Edition, 2008.

BÖHMEROVÁ Ada, “Feminine Markers - First, Last, Last But Not Least, Or Will They at All Last?”, Universitas Comeniana, Philologica LX. Eighty Years of English Studies at the Faculty of Arts, Bratislava, Univerzita Komenského, 2004: 43-53.

BÖHMEROVÁ Ada, Slovak for You. Slovak for Speakers of English for Beginners and Intermediate Students, $4^{\text {th }}$ revised and extended edition, Bratislava, Perfekt - Wauconda, Bolchazy-Carducci, USA, 2006.

BÖHMEROVÁ Ada (co-author), English-Slovak - Slovak-English Dictionary, Bratislava, Ottovo nakladatelství (forthcoming).

CHAMONIKOLASOÁ Jana \& RAMBOUSEK Jiří, “Diminutive expressions in translation: a comparative study of English and Czech", Belgian Journal of Linguistics 21, Amsterdam, John Benjamins Publishing Company (NDL), Volume 21, Number 1, 2007: 51-67.

CZAMBEL Samuel, RukoväŤ spisovnej reči slovenskej, Martin, 1919.

DOKULIL Miloš, Tvoření slov v češtině 1 . Teorie odvozování slov, Praha, ČAV, 1962. 
DOLNík Juraj, Jazyk a hodnotenie, Banská Bystrica, Univerzita Mateja Bela, 1999.

DRESSLER Wolfgang U. \& MERLINI BARBARESI Lavinia, Morphopragmatics. Diminutives and Intensifiers in Italian, German and Other Languages, Berlin, Mouton de Gruyer, 1994.

FILIPEC Josef \& ČERMÁK František, Česká lexikologie, Praha, Academia, 1985.

FURDík Juraj, Slovenská slovotvorba, ed. Martin Ološtiak, Prešov, Náuka, 2004.

GLADKOVA Hana, "Deminutiva v bulharštině a v češtině”, in ČERMÁK, František. a KOCEK, Jan (eds.), Mnohojazyčný korpus InterCorp: Možnosti studia, Nakladatelství Lidové Noviny, Praha, 2010 (forthcoming).

GLADKOVA Hana, “Centrum a periferie kategorie deminutivnosti (Co ukázala sonda do paralelního korpusu)”, Človek a jeho jazyk. Zborník z konferencie v Smoleniciach venovanej profesorovi Jánovi Horeckému, Bratislava, SAV, 2010 (forthcoming).

GREGOVÁ Renáta \& PANOCovÁ Renáta, “On Phonetic Iconicity in Evaluative Morphology of Slavonic Languages", Galicia English Teachings: Old Pitfalls, Changing Attitudes and New Vistas, Rzeszów, Wydavnictwo Uniwersytetu Rzeszowskiego, 2009: 43-50.

HORECKÝ Ján, “Zdrobneniny. Zveličujúce názvy”, Slovenská lexikológia, Bratislava, Slovenské pedagogické nakladateL'stvo, 1971: 163-168.

HORECKÝ Ján, Základy Jazykovedy, Bratislava, Slovenské pedagogické nakladateL’stvo, 1978.

HORECKÝ Ján \& RÁCOVÁ Anna, Slovník jazykovedných termínov, Bratislava, Slovenské pedagogické nakladateL'stvo, 1979.

JÁNošík Anton, “Gramatický a prirodzený rod augmentatív na -isko”, Slovenská reč 13, No. 1-2, 1947/48: 17-25.

KÁŇA Tomáš, “Česká substantivní deminutiva a jejich protějšky v němčine a angličtině”, in ČERMÁK František \& KocEK Jan (eds.), Mnohojazyčný korpus InterCorp: Možnosti studia. Nakladatelství Lidové Noviny, Praha, 2010.

KÖRTVÉLYESSY Lívia, “A Cross-Linguistic Research into Phonetic Iconicity”, Lexis 6, 2011: 27-39: http://screcherche.univ-lyon3.fr/lexis/spip.php?article169

Krátky slovník slovenského jazyka (KSSJ), KAČALA Ján \& PISÁRČIKOVÁ Mária (eds.), Bratislava, Veda, 1997.

MATHESIUS Vilém, “Funkční lingvistika”, Sbornik přednášek přednesených na Prvém sjezdu československých profesorů filozofie, filologie a historie v Praze 3. - 7. dubna 1929. Praha, Stálý přípravný výbor sjezdový, 1929: 118-130. [also in MATHESIUS Vilém, Jazyk, kultura a slovesnost, Praha: Odeon, 1982: 29-38.

MISTRíK Jozef et al. (eds), Encyklopédia jazykovedy, Bratislava, Obzor, 1993.

NÁBĚLKOVÁ Mira, “Domiská, knižiská, psiská a iné modifikačné substantívne deriváty v slovenskočeskom poh'ade”, Zborník z konferencie venovanej PhDr. Kláre Buzássyovej, Bratislava, Veda, 2010 (forthcoming).

ONDRUS Pavel, HORECKÝ Ján \& FURDÍK Juraj, Súčasný slovenský spisovný jazyk. Lexikológia, Bratislava, Slovenské pdagogické nakladateL'stvo, 1979.

ORAVEC Ján, BAJZÍKOVÁ Eugénia \& FURDÍK Juraj, Súčasný slovenský spisovný jazyk. Morfológia, Bratislava, Slovenské pedagogické nakladateL’stvo, 1988. 
PLAG Ingo, Word-Formation in English, Cambridge, Cambridge University Press, 2009.

PLANK Frans \& FILIMONOVA Elena, The Universals Archive, Retrieved 20.02.2010 from http://ling.unikonstanz.de/pages/proj/sprachbau.htm

RONČÁKOVÁ Terézia, “Štýlové presahy v náboženskej publicistike”, Slavica Slovaca 2, 2009: 119-148.

SCALISE Sergio, Generative Morphology, Dordrecht, Foris, 1984.

SCHNEIDER Klaus P., Diminutives in English, Tübingen, Niemeyer, 2003.

SMIEŠKovÁ Elena, “Augmentatíva a ich miesto v slovníku spisovného jazyka”, Slovenská reč, 21, No. 1-2, 1956: 79-81.

STUMP Gregory T., "How Peculiar is Evaluative Morphology?", Journal of Linguistics 29, 1993: 1-36.

ŠTEKAUER Pavol, "Onomasiological Theory of Word-formation", in Encyclopaedia of Language and Linguistics. Oxford, Elsevier, Vol. 9, 34-7.

ŠTEKAUER Pavol, GREGoVÁ Renáta, KOLAŘíKOVÁ Zuzana, KÖRTVÉLYESSY Lívia \& PANOCoVÁ Renáta, “On phonetic iconicity in evaluative morphology. Languages of Europe", in ŠTEKAUER, Pavel, TOMAščíKovÁ Slávka \& WiTAŁISZ Wladisław (eds), Culture, Language and Literature Across Border Regions, Krosn, PWSZK, 2009.

VACHEK Josef (ed.), A Prague School reader in linguistics, Bloomington, Indiana University Press, 1966.

\section{ABSTRACTS}

The paper primarily focuses on the synchronical suffixal means forming diminutives and augmentatives in Slovak, presenting a basic research in these areas. It is aimed at their identification, distribution in the particular word-classes, systemic status within evaluative morphology, and the analysis of some of the semantic features and pragmatic aspects of suffixal diminutives and augmentatives. Included are also several cross-linguistic considerations within the wider context of some of the relevant phenomena.

INDEX

Keywords: evaluative morphology, onomasiological category, synchronic view, diminutive, augmentative, morphological analysis, word-classes, semantic and pragmatic functions

\section{AUTHOR}

\section{ADA BÖHMEROVÁ}

Comenius University, Bratislava, Slovak Republic

bohmerovaada@yahoo.com 